\title{
Effect of Schisandra chinensis (Turcz) Schisandraceae seed extracts and cisplatin on cytotoxicity, genotoxicity and wound healing in MCF-7 cells
}

\author{
Liang-Mei Li ${ }^{1 *}$, Jing Yang ${ }^{2}$ \\ ${ }^{1}$ Department of Respiratory Medicine, Ji'nan Zhangqiu District Hospital of Traditional Chinese Medicine, Ji'nan, Shandong \\ 250200, , Department of Cardiology, Jinan First People's Hospital, Ji'nan, Shandong 250000, China
}

*For correspondence: Email: drliangmei@hotmail.com; Tel/Fax: 0086-0531-83265046

\begin{abstract}
Purpose: Schisandra chinensis is a plant used in traditional Chinese and Russian medicine. An S. chinensis seed extract was tested for its ability to potentiate the effects of the anticancer agent cisplatin in MCF-7 breast cancer cells.

Methods: S. chinensis seeds were extracted with ethanol and the ethanol was evaporated from the extracts to obtain an aqueous fraction of the $S$. chinensis seed extract (SCSE). MCF-7 cells were exposed to cisplatin alone or in combination with various concentrations of SCSE. The end points that were measured were cytotoxicity, genotoxicity, and wound healing.

Results: The addition of $10 \%$ SCSE increased the cytotoxicity of cisplatin by increasing MCF-7 cell death by $7 \%$. The combination of $20 \%$ SCSE and cisplatin completely inhibited wound healing in MCF7 cells. SCSE alone did not induce DNA fragmentation in MCF-7 cells.

Conclusion: Compounds from S. chinensis seed extracts may mitigate cancer cell proliferation and migration.
\end{abstract}

Keywords: Schisandra chinensis, MCF-7 cells, Cytotoxicity, Genotoxicity, Wound healing, Cisplatin

\begin{abstract}
This is an Open Access article that uses a funding model which does not charge readers or their institutions for access and distributed under the terms of the Creative Commons Attribution License (http://creativecommons.org/licenses/by/4.0) and the Budapest Open Access Initiative (http://www.budapestopenaccessinitiative.org/read), which permit unrestricted use, distribution, and reproduction in any medium, provided the original work is properly credited.

Tropical Journal of Pharmaceutical Research is indexed by Science Citation Index (SciSearch), Scopus, International Pharmaceutical Abstract, Chemical Abstracts, Embase, Index Copernicus, EBSCO, African Index Medicus, JournalSeek, Journal Citation Reports/Science Edition, Directory of Open Access Journals (DOAJ), African Journal Online, Bioline International, Open-J-Gate and Pharmacy Abstracts
\end{abstract}

\section{INTRODUCTION}

Schisandra chinensis is a dioecious plant that is native to northern China and several regions of Russia. S. chinensis is cultivated for its berries, which are used in teas, wines, confectionaries, and as flavoring agents. The berries are known as 'five-flavored berries' for their combination of five tastes. S. chinensis is considered an adaptogen because it is beneficial to human health, does not cause side effects or toxicity, and is one of the 50 herbs that are fundamental to traditional Chinese medicine [1]. The seeds of $S$. chinensis are used to treat respiratory, urinary, hepatic, nervous, and digestive ailments [2]. $S$. chinensis is also used for medicinal purposes in Russia, where scientific studies of $S$. chinensis are well documented [3]. Extracts of $S$. chinensis contain high levels of schisandrin $B$, which has significant antichlamydial activity and is safe for humans [4]. 
The phytochemical composition of $S$. chinensis and the physical and chemical properties of its primary compounds are well known [5-7]. The primary beneficial compounds in S. chinensis are the lignins schisandrin and gomisin A, which play important roles in the adaptive immune response [8]. Lignins stimulate the production of cytokines, including interleukin-8, granulocyte-macrophage colony-stimulating factor, and macrophage inflammatory protein-1 $\beta$ [9].

S. chinensis seed extracts (SCSEs) have been shown to inhibit the growth of cultured human breast cancer cells by arresting the cell cycle [10]. The in vivo effects of SCSEs have also been studied using mouse and rat models. Multiple studies have demonstrated the hepatoprotective effects of SCSEs [11-13] and have evaluated the toxicity of gomisin $A$ in rats [14-16].

MCF-7 is a human breast cancer cell line that is routinely used to evaluate drug actions, tumor microenvironments, and drug efficacy [17]. MCF7 has been used to study the effects of cisplatin in combination with a modulatory agent, ginsenoside compound K [18]. In this study, we tested the combinatorial effects of SCSEs and cisplatin on MCF-7 cells, and we used genotoxicity and wound healing as the evaluation endpoints.

\section{EXPERIMENTAL}

\section{Plant materials and extracts}

An SCSE was obtained by soaking $500 \mathrm{~g}$ of airdried S. chinensis seeds with $95 \%$ ethanol ten times as described previously [19]. The SCSE was filtered and the ethanol was evaporated. After evaporation, a $50 \mathrm{~mL}$ aqueous fraction remained. The aqueous fraction was filtersterilized using a $0.22 \mu \mathrm{m}$ filter, aliquoted, and stored at $4{ }^{\circ} \mathrm{C}$ until further use.

\section{Cell culture}

The MCF-7 cell line was cultured as a monolayer in DMEM supplemented with $10 \%$ fetal bovine serum. Cells were seeded in $1 \mathrm{~mL}$ of medium in 24-well plates at a density of $0.12 \times 10^{6} \mathrm{cells} / \mathrm{mL}$. The cytotoxicity, genotoxicity, and wound healing experiments were performed in duplicate.

\section{Evaluation of cytotoxicity and genotoxicity}

Cisplatin-induced cytotoxicity and genotoxicity were evaluated by treating cells with $2.5,5,7.5$, $10,12.5,15,17.5,20,22.5,25,27.5$, or $30 \mu \mathrm{M}$ cisplatin for $24 \mathrm{~h}$. The trypan blue assay was used to evaluate cytotoxicity and DNA fragmentation. After exposure to cisplatin, cells were trypsinized and harvested, and the trypan blue assay with the Neubauer chamber was used to calculate the percentages of live and dead cells. The half-maximal inhibitory concentration $\left(\mathrm{IC}_{50}\right)$ value for cisplatin-induced cytotoxicity were determined. In addition, DNA was extracted from cells that were exposed to various concentrations of cisplatin using the standard salting-out method. DNA concentration and purity were measured using a NanoDrop ${ }^{\mathrm{TM}}$ spectrophotometer. DNA electrophoresis was performed using standard agarose gels and gels were viewed using a Gel Doc ${ }^{\mathrm{TM}}$ image analysis system.

Cells were cultured in 24-well plates and incubated with $25,27.5$, or $30 \mu \mathrm{M}$ cisplatin for 24 h. After incubation, the wells were washed three times with $1 \mathrm{~mL}$ of phosphate-buffered saline. Then, the cells were then scratched with a 200 $\mu \mathrm{L}$ pipette and wound healing was monitored 24 $\mathrm{h}$ later.

Cells were cultured in 24-well plates and were incubated with $2,5,10,15$, or $20 \%$ SCSE (v/v) for $24 \mathrm{~h}$. After incubation, cells were harvested for cytotoxicity and genotoxicity assays. Cells were cultured in 24-well plates and were incubated with $11.3 \mu \mathrm{M}$ cisplatin and 2, 5, 10, 15, or $20 \%$ SCSE $(\mathrm{v} / \mathrm{v})$ for $24 \mathrm{~h}$. Following incubation, the cells were harvested for cytotoxicity and genotoxicity assays. Wound healing assays were performed with cells that were incubated with a combination of $11.3 \mu \mathrm{M}$ cisplatin and $2,5,10,15$, or $20 \%$ SCSE (v/v) for $24 \mathrm{~h}$. Following incubation, the wounds were analyzed to determine healing rates.

\section{Statistical analysis}

All of the experiments were performed in triplicate and values were averaged. ${ } \mathrm{C}_{50}$ values were plotted as graphs with standard deviations, error bars, and R-values. DNA fragmentation and wound healing data are presented as images.

\section{RESULTS}

\section{Cisplatin-induced cytotoxicity, genotoxicity, and wound healing}

Trypan blue assays revealed that the $\mathrm{IC}_{50}$ of cisplatin in MCF-7 cells was $11.3 \mu \mathrm{M}$ (Figure 1). Cisplatin concentrations of $2.5,5,7.5,10,12.5$, $15,17.5,20,22.5$, or $25 \mu \mathrm{M}$ did not induce DNA fragmentation, whereas 27.5 and $30 \mu \mathrm{M}$ cisplatin induced DNA fragmentation in MCF-7 cells (Figure 2). 


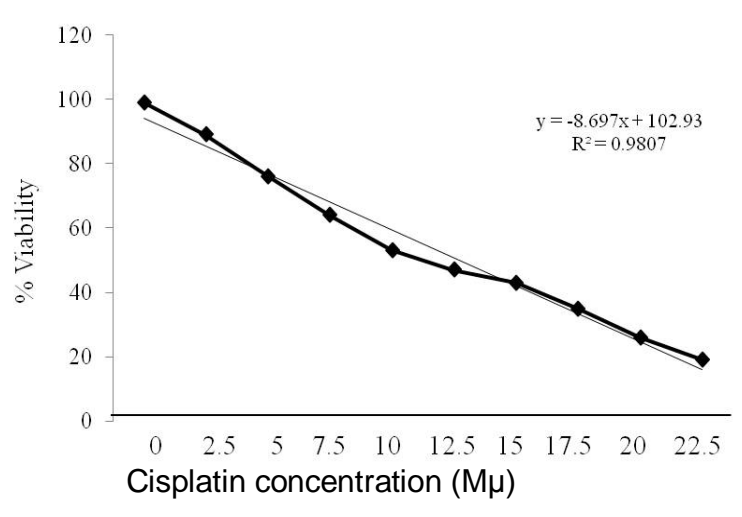

Figure 1: Effect of cisplatin on cell viability

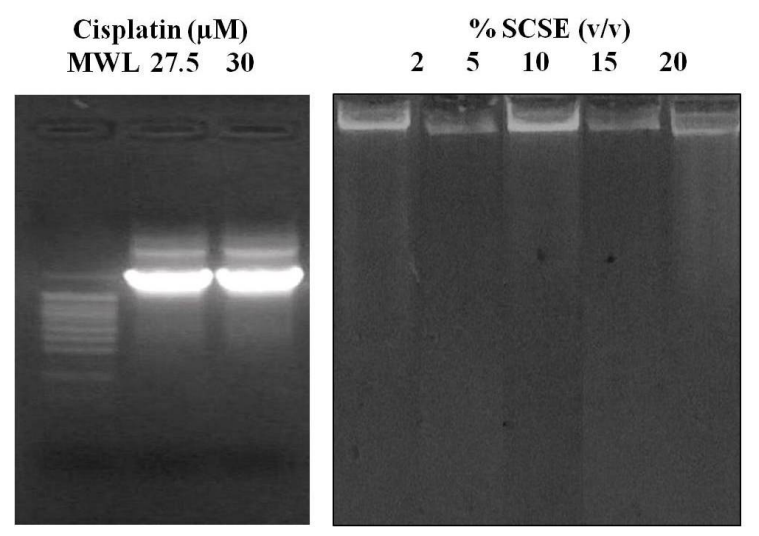

Figure 2: Effect of cisplatin SCSE on DNA fragmentation in MCF-7 cells. MCF-7 cells were incubated with $2.5,5,7.5,10,12.5,15,17.5,20,22.5$, $25,27.5$, or $30 \mu \mathrm{M}$ cisplatin, and 27.5 and $30 \mu \mathrm{M}$ cisplatin induced DNA fragmentation, whereas lower cisplatin concentrations did not induce DNA fragmentation. MCF-7 cells were incubated with 2, 5, 10,15 , or $20 \%$ SCSE, and none of these SCSE concentrations induced DNA fragmentation indicating that SCSE is not toxic to MCF-7 cells. MWL indicates the molecular weight ladder
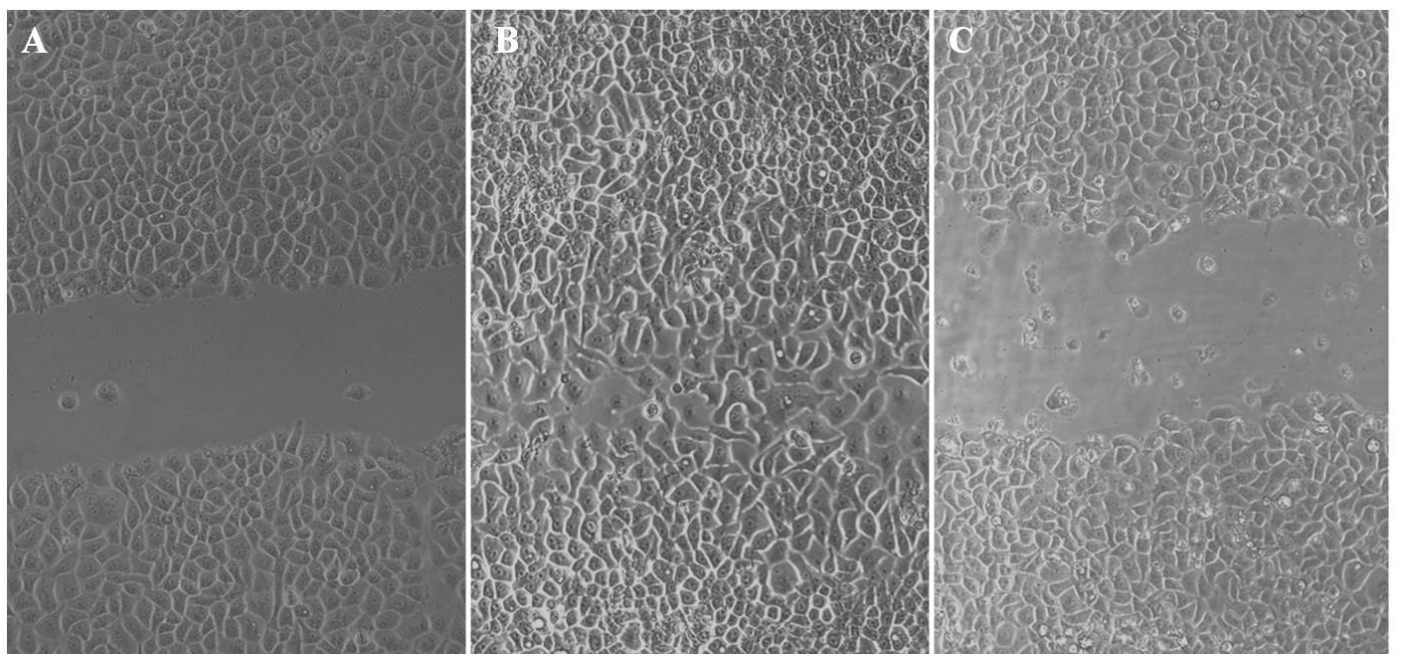

Figure 3: Effect of cisplatin SCSE on wound healing in MCF-7 cells. (A) Control MCF-7 cells with an induced wound at time 0 . (B) Control MCF-7 cells showed complete wound healing after $24 \mathrm{~h}$. (C) MCF-7 cells treated with $20 \%$ SCSE $(\mathrm{v} / \mathrm{v})$ and $1.3 \mu \mathrm{M}$ cisplatin showed incomplete wound healing after $24 \mathrm{~h}$
The wounds on control cells healed fully within $24 \mathrm{~h}$, whereas the wounds on cells treated with $25,27.5$, or $30 \mu \mathrm{M}$ cisplatin did not heal completely (Figure 3 ).

\section{Effect of SCSE on MCF-7 cells}

Cells exposed to $2,5,10,15$, or $20 \%$ SCSE for $24 \mathrm{~h}$ exhibited wild-type morphologies, culture characteristics, viability, DNA integrity, and wound healing.

\section{Effect of cisplatin and SCSE on MCF-7 cells}

The $\mathrm{IC}_{50}$ of cisplatin on MCF-7 cells was 11.3 $\mu \mathrm{M}$, however cytotoxicity increased when cells were treated with $11.3 \mu \mathrm{M}$ cisplatin and 2, 5, 10, 15 , or $20 \%$ SCSE $(v / v)$ for $24 \mathrm{~h}$. Treatment with $11.3 \mu \mathrm{M}$ cisplatin and $10 \%$ SCSE $(\mathrm{v} / \mathrm{v})$ resulted in $43 \%$ MCF-7 cell viability (Figure 4 ), however, cell viability did not decrease further when 11.3 $\mu \mathrm{M}$ cisplatin was combined with 15 or $20 \%$ SCSE.

DNA fragmentation was not observed in cells treated with $0,2,5,10,15$, or $20 \%$ SCSE (v/v) and $11.3 \mu \mathrm{M}$ cisplatin. Incomplete wound healing was observed in cells that were cultured with $11.3 \mu \mathrm{M}$ cisplatin and 2, 5, or $10 \%$ SCSE $(\mathrm{v} / \mathrm{v})$ for $24 \mathrm{~h}$. No wound healing was observed in cells that were treated with $11.3 \mu \mathrm{M}$ cisplatin and 15 or $20 \%$ SCSE $(v / v)$ for $24 \mathrm{~h}$.

\section{DISCUSSION}

S. chinensis is well known for its medicinal properties and has been used in traditional medicine, especially in China and Russia. 


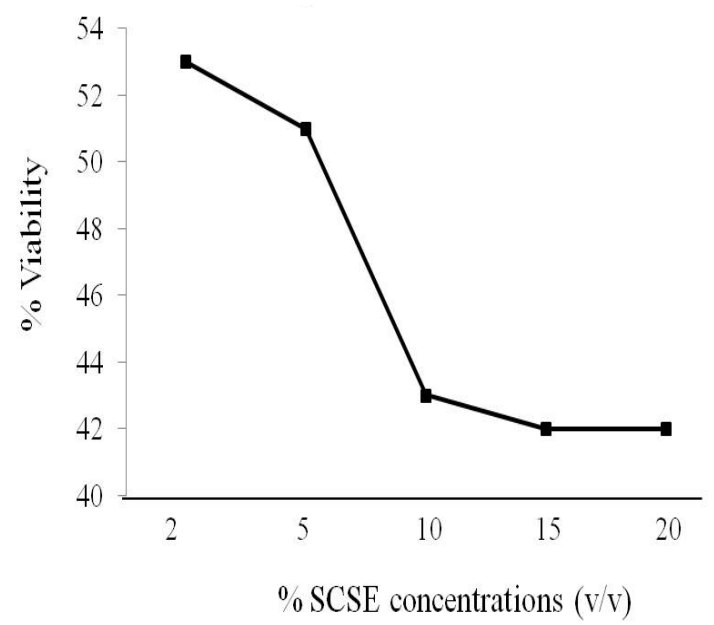

Figure 4: Effect of a combination of cisplatin and SCSE on cell viability. IC $\mathrm{C}_{50}$ of cisplatin on MCF-7 cells was $11.3 \mu \mathrm{M}$. MCF-7 cell cytotoxicity increased upon the addition of SCSE with $11.3 \mu \mathrm{M}$ cisplatin. A combination of 15 or $20 \%$ SCSE and $11.3 \mu \mathrm{M}$ of cisplatin reduced MCF-7 cell viability to approximately $43 \%$ compared to $53 \%$ for cisplatin alone

The active compounds in $S$. chinensis seeds have been characterized and several animal studies have shown the beneficial effects of $S$. chinensis phytochemicals, for example, it has been shown that $S$. chinensis extracts can induce cell-cycle arrest in breast cancer cells [10]. S. chinensis extracts have also been tested in combination with other chemotherapeutic agents, including carbon tetrachloride, halothane, 3'-methyl-4-dimethylamino-azobenzene,

deoxycholic acid, hepatotoxins, hydrogen peroxide, and doxorubicin [20]. In this study, we showed that SCSE modulates cisplatin-induced cytotoxicity in MCF-7 cells, thus supplementation with SCSE could reduce the cisplatin concentration required to reach the $\mathrm{IC}_{50}$ value. We initially hypothesized that SCSE may retard wound healing in MCF-7 cells indicating a potential role in the control of cancer cell migration and metastasis, however, we did not observe any genotoxic effects of SCSE on MCF7 cells. Rather, we found that SCSE may be useful in cancer therapeutics because it is nontoxic and augments the cytotoxicity of the chemotherapeutic drug cisplatin.

\section{CONCLUSION}

Cisplatin is a commonly used cancer chemotherapeutic drug, which induces cellular apoptosis through the formation of DNA adducts, and the MCF-7 cell line is also widely used in cancer research, thus we chose cisplatin and the MCF-7 cell line for this study. In this study, we demonstrated the potential of SCSE as a useful adjuvant for chemotherapy that could reduce the doses of chemotherapeutic drugs given to patients. Nevertheless, in vivo studies are still required to determine the translational potential of SCSE to human clinical applications.

\section{DECLARATIONS}

\section{Acknowledgement}

The authors thank the District Hospital of Traditional Chinese Medicine, Ji'nan, Shandong 250200 and The Department of Cardiology, Ji'nan First People's Hospital, Ji'nan, Shandong 250000 , China for the support that they provided to undertake and complete this work.

\section{Conflict of interest}

The authors declare that they have no conflicts of interest.

\section{Author contributions}

We declare that this work was done by the authors named in this article and all liabilities pertaining to claims relating to the content of this article will be borne by the authors. Both authors contributed equally to the experimental design, data collection, interpretation of results, and manuscript preparation.

\section{REFERENCES}

1. Chevallier $A$. The encyclopedia of medicinal plants. DK Publishing, New York, 1996.

2. Hikino $H$, Kiso $Y$, Taguchi $H$, lkeya Y. Antihepatotoxic actions of lignoids from Schisandra chinensis fruits. Planta Medica 1984; 50(3): 213-218.

3. Panossian A and Wikman G. Russian research and uses in medicine. J Ethnopharmacol 2008; 118(2): 183-212.

4. Xu XM, Li L, Chen M. Studies on the chemical constituents of Schisandra pubescens. Zhong Yao Cai 2009; 32(9): 1399-13401.

5. Ikeya Y, Taguchi $H$, Yosioka I, Kobayashi $H$. The constituents of Schizandra chinensis Baill. I. Isolation and structure determination of five new lignans, gomisin $A, B, C, F$, and $G$, and the absolute structure of schizandrin. Chem Pharm Bull (Tokyo) 1979; 27(6): 1383-1394.

6. Ikeya $Y$, Taguchi $H$, Yosioka I, Kobayashi $H$. The constituents of Schizandra chinensis BAILL BIII. The structures of two new lignans, tigloylgomisin $P$ and angeloylgomisin P. Chem Pharm Bull (Tokyo) 1980; 28(11): 3357-3361.

7. Lin RD, Mao YW, Leu SJ, Huang CY, Lee MH. The immuno-regulatory effects of Schisandra chinensis and its constituents on human monocytic leukemia cells. Molecules 2011; 16(6): 4836-4849. 
8. Song WZ, Tong YY. The occurrence of some important lignans in Wu Wei Zi (Schisandra chinensis) and its allied species. Yao Xue Bao [in Chinese] 1983; 18(2): 138-143.

9. Guo $L Y$, Hung $T M$, Bae $K H$ et al. Anti-inflammatory effects of schisandrin isolated from the fruit of Schisandra chinensis Baill. Eur J Pharmacol 2008; 591(1-3): 293-299.

10. Hendrich S, Bjeldanes LF. Effects of dietary Schizandra chinensis, brussels sprouts and Illicium verum extracts on carcinogen metabolism systems in mouse liver. Food Chem Toxicol 1986; 24(9): 903-912.

11. Cui $Y Y$, Wang MZ. Metabolic transformation of schizandrin [in Chinese]. Yao Xue Bao 1992; 27(1): 5763.

12. Cui YY, Wang MZ. Aspects of schizandrin metabolism in vitro and in vivo. Eur J Drug Metab Pharmacokinet 1993; 18(2): 155-160.

13. Mizoguchi $Y$, Kawada N, Ichikawa $Y$, Tsutsui H. Effect of gomisin $A$ in the prevention of acute hepatic failure induction. Planta Med 1991; 57(4): 320-324.

14. Nomura M, Ohtaki $Y$, Hida $T$, Aizawa $T$, Wakita $H$, Miyamato K. Inhibition of early 3'-methyl-4dimethylaminoazobenzene-induced hepatocarcinogenesis by gomisin A in rats. Anticancer Res 1994; 14(5A): 1967-1971.

15. Miyamoto K, Hiramatsu K, Ohtaki Y, Kanitani M, Nomura $M$, Aburada $M$. Effects of gomisin $A$ on the promotor action and serum bile acid concentration in hepatocarcinogenesis induced by 3'-methyl-4dimethylamino-azobenzene. Biol Pharm Bull 1995; 18(10): 1443-1445.

16. Zhu YX, Yan KD, Tu GS. Chemical studies on Sheng Mai San. Part 1. Quantitative determination of active ingredients of schizandra in Sheng Mai San by TLCdensitometry. Chin J Pharm Anal 1988; 8: 71-73.

17. Zhang $K, L i Y$. Effects of ginsenoside compound $K$ combined with cisplatin on the proliferation, apoptosis and epithelial mesenchymal transition in MCF-7 cells of human breast cancer. Phytother Res 2010; 24(2): 193197.

18. Lin R-D, Mao Y-W, Leu S-J, Huang C-Y, Lee M-H. The immuno-regulatory effects of Schisandra chinensis and its constituents on human monocytic leukemia cells. Molecules 2011; 16: 4836-4849.

19. Maeda S, Takeda S, Miyamato Y, Aburada M, Harada M. Effects of gomisin $A$ on liver functions in hepatotoxic chemicals-treated rats. Jpn J Pharmacol 1985; 38(4): 347-353.

20. Pao TT, Liu KT, Hsu KF, Sung C-Y. Studies on Fructus schizandre 1. Effects on increased SGPT levels in animals caused by hepatotoxic chemical agents [in Chinese]. Chung-hua I Hsueh Tsa Chih 1974; 54: 275277. 